\title{
Comparative evaluation of renal, pleiotropic and myotropic effects of statins in rats
}

\author{
V.G. Zeleniuk, I.I. Zamorskii, O.V. Gerush, T.S. Shchudrova, \\ O.M. Goroshko, A.R. Zeleniuk
}

Higher state educational establishment of Ukraine "Bukovinian state medical university”, Chernivtsi; e-mail:vzeleniuk@gmail.com

The effect of certain statins with different lipophilicity (atorvastatin (ATO), lovastatin (LOV), simvastatin (SIM)) on renal function of apparently healthy rats at a conventionally effective dose of $20 \mathrm{mg} / \mathrm{kg}$ was established. As it has been found in our experiments on the $7^{\text {th }}$ day of statins administration there was only a slight increase in urine output along with a moderate growth of glomerular filtration rate (GFR) and decrease in excretion of sodium ions and protein while maintaining the mechanisms of intrarenal autoregulation. Renotropic action of statins, among various mechanisms, was evoked by their pleiotropic effects what was confirmed by the presence of correspondent correlations. Antioxidant effect of drugs was evidenced by decreased malondialdehyde (MDA) content and increased catalase (CAT) activity, as well as by reducing trend of blood plasma proinflammatory cytokines (interleukin-1 $\beta(I L-1 \beta)$, interleukin-6 (IL-6) and tumor necrosis factor alpha $(T N F-\alpha))$. An absence of statins influence on blood plasma transaminase levels, blood plasma creatine phosphokinase (CPK) activity and skeletal muscles histostructure was also demonstrated. The most marked renal effect was demonstrated by SIM - the most lipophilic drug among the studied ones.

Key words: statins; renal function; apparently healthy rats: prooxidant-antioxidant balance; interleukins

\section{INTRODUCTION}

Statins are widely used in the pharmacotherapy of hypercholesterolemia-induced cardiovascular-associated diseases [1]. Alongside this, their pleiotropic effects condition the investigations aimed to study the influence of statins on the pathogenetic mechanisms of a number of diseases, and specifically renal failure - each of chronic [2] and acute [3]. The main mechanisms of renoprotective action of statins are considered to be: antiproliferative, anti-inflammatory, immunomodulatory, antioxidant and antithrombotic effects as well as normalization of endothelial dysfunction [4-7]. In recent studies it was established that by up-regulating the expression levels of the membrane water channels aquaporin 2 statins increase water reabsorption by the kidney [8]. Also statins may interact with the renin-angiotensin-aldosterone system (RAAS) in a number of ways i.e. to decrease the expression of receptors for angiotensin II, inhibit the angiotensin II-dependent intracellular signaling, reduce the RAAS-dependent oxidative stress and inflammation as well as inhibit the synthesis of angiotensin II and aldosterone [9]. So, statins may affect the renal function both directly and indirectly in case of the disturbances of homeostasis. The direct renotropic action of statins is verified by the results of studies in healthy subjects after a single administration and short-term use, in which only minor changes of renal processes were established: an increase in a fractional sodium excretion and a reduction in a diastolic blood pressure [10].

However there is lack of data on the impact of statins on renal function and some other physiological processes in apparently healthy rats on long-term drugs administration taking into account their possible side effects. Serum levels of creatine phosphokinase (CPK), alanine transaminase (ALT) and aspartate transaminase AST are the most frequently observed surrogate markers of

(C) V.G. Zeleniuk, I.I. Zamorskii, O.V. Gerush, T.S. Shchudrova, O.M. Goroshko, A.R. Zeleniuk 
cellular injury following the statins therapy, that's why these parameters were assessed in the present study [11]. What is more, statins have different lipophilicity, thereby performing differences in their efficacy profile, so it is reasonable to compare several drugs: ATO, LOV, SIM (drugs listed in order of increasing of relative lipophilicity).

Our research was targeted at the comparative study of the effects of certain statins on renal function in apparently healthy rats, the verification of several mechanisms of drugs action with the assessment of their side effects.

\section{METHODS}

Experimental studies were carried out on 28 nonlinear mature male white rats weighting 140-180 g. Animals were taken from the vivarium of HSEE of Ukraine "Bukovinian State Medical University" (BSMU). Within one month before and during the experiment the animals were kept in the laboratory vivarium in conditions of constant temperature $\left(18-21^{\circ} \mathrm{C}\right)$ and humidity (50-55\%), in individual metabolic cages with free access to drinking water and food. All interventions were conducted according to the criteria outlined in the Directive 2010/63/EU of the European Parliament and of the Council on the protection of animals used for scientific purposes (2010).

The rats were randomly distributed into 4 experimental groups: control (CON), ATO, LOV, SIM; each group of 7 animals. Rats in the control group received physiological saline through the gastric tube. Those rats in ATO, LOV, SIM groups received ATO (Farmak JSC, Kyiv, Ukraine) at a previously established conventionally effective daily dose of $20 \mathrm{mg}$ / kg, LOV (JSC “Kyivmedpreparat”, Kyiv, Ukraine) - at a daily dose of $20 \mathrm{mg} / \mathrm{kg}$, and SIM (PrJSC "Pharmaceutical Firm "Darnitsa", Kyiv, Ukraine) - at a daily dose of $20 \mathrm{mg} / \mathrm{kg}$ [12]. Statins were administrated through gastric tube in an amount of $1 \mathrm{ml}$ of $1 \%$ starch solution per $100 \mathrm{~g}$ of the body weight.
Effect of statins on renal function in rats was investigated under the conditions of water load (intragastric administration of drinking water in a volume of $5 \%$ of the body weight, followed by collection of urine during 2 hours). The urine was examined for protein, creatinine, sodium, potassium levels and gamma-glutamyltransferase (GGT) activity. At the end of the experiments, all rats were sacrificed by decapitation under pentobarbital anesthesia $(80 \mathrm{mg} / \mathrm{kg})$. The part of thigh skeletal muscle was put into $10 \%$ formaldehyde solution for histopathological examination and left kidney was preserved at $-80^{\circ} \mathrm{C}$ until analysis of MDA, superoxide dismutase (SOD), CAT, glutathione peroxidase (GPx) levels was performed. The blood was stabilized with heparin solution and examined for total cholesterol (TC) and low-density lipoprotein (LDL), creatinine, sodium, potassium levels, CPK, ALT and AST activity [13].

Plasma and urine creatinine levels were determined using the Jaffe reaction; sodium and potassium ions levels - using electronic flame photometry method; urine protein content using the sulfosalicylic acid precipitation test; urine GGT activity - using the Szasz procedure [14]. The plasma levels of interleukin-1 $\beta$ (IL$1 \beta$ ), interleukin-6 (IL-6) and tumor necrosis factor alpha (TNF- $\alpha$ ) were assessed using the enzyme-linked immunosorbent assay applying reagent kits by ZAO "Vector-Best" (Novosibirsk, Russian Federation). The protein content of the supernatant was determined using the Lowry method.

The thigh skeletal muscle fragments of the rats were embedded in paraffin, sectioned at 5 $\mu \mathrm{m}$ thickness and then stained with hematoxylin and eosin. The preparations were evaluated by light microscope and photographed (Olympus C740UZ photo camera, Tokyo, Japan, LUMAMR8 microscope, LOMO, St. Petersburg, Russian Federation). Renal tissue injury index was performed by means of the quantitative analysis in the environment of computer software "VideoTest - Razmer 5.0" (LLC "VideoTest", Russian Federation). 
Statistical analysis of the data was performed using PAST statistical software (a freeware). All data are represented as a mean \pm standard deviation of a sample $(\mathrm{M} \pm \mathrm{m})$. Estimation of the differences between the samples was conducted using nonparametric Mann-Whitney U test. Spearman rank correlation was used to test the association between variables. The level of significance was $\mathrm{P} \leq 0.05$.

\section{RESULTS}

Under the influence of statins some changes of renal function were observed (Table 1). To illustrate: SIM and ATO statistically significantly increased urine output by $20 \%$ and $12 \%$ respectively, increase in GFR was irrelevant by $8 \%$ on average in the absence of changes in plasma creatinine concentration in all groups. ATO and SIM demonstrated a tendency to increase potassium excretion, which was notable, but not statistically significant. The excretion of sodium ions under the influence of all statins increased on average by $32 \%$ mainly due to trend in decrease of sodium reabsorption in the proximal tubules by an average of $13 \%$ and in the distal tubules - by $16 \%$ with almost unchanged values of filtration fraction, absolute sodium reabsorption and fractional excretion of sodium. The urine protein content in all groups of treated animals was 2 times less than in CON group along with similar changes for urinary protein excretion.

Describing the interrelations between different nephron sectors, we noted a preservation of an intrarenal autoregulation under the use of statins. The latter fact was demonstrated by a number of interconnections. A tubular-tubular link was brought out with negative correlation between proximal and distal sodium transport amounted to $r=-0.76$ in ATO, $r=-0.96$ in LOV and $r=-0.96$ in SIM. The strong positive correlations between sodium filtration fraction and its proximal reabsorption $(\mathrm{r}=0.96$ in ATO, $\mathrm{r}=0.99$ in LOV and $r=0.96$ in SIM), and between GFR and absolute sodium reabsorption $(\mathrm{r}=0.97$ in ATO, $r=0.98$ in LOV and $r=0.96$ in SIM) provide evidence of the normal functioning of the glomerular-tubular balance. Tubular-glomerular feedback was characterized by negative ratio

Table 1. Indicators of kidney function of rats after 7 days of statins administration $(M \pm m ; n=7)$

\begin{tabular}{lcccc|}
\hline \multicolumn{1}{c}{ Parameter (units) } & CON & ATO & LOV & SIM \\
\hline Urine output, ml/2 h & $3.52 \pm 0.14$ & $3.95 \pm 0.09^{*}$ & $3.78 \pm 0.08$ & $4.23 \pm 0.19^{*}$ \\
$\mathrm{P}_{\mathrm{cr}}, \mu \mathrm{mol} / \mathrm{l}$ & $57.2 \pm 3.3$ & $59.9 \pm 4.5$ & $54.6 \pm 4.5$ & $62.6 \pm 4.9$ \\
$\mathrm{GFR}, \mu \mathrm{l} / \mathrm{min}$ & $370.7 \pm 25.4$ & $402.7 \pm 32.5$ & $393.7 \pm 46.7$ & $405.7 \pm 38.1$ \\
Urine protein content, g/l & $0.026 \pm 0.003$ & $0.015 \pm 0.002^{*}$ & $0.011 \pm 0.001^{*}$ & $0.013 \pm 0.002^{*}$ \\
Urine protein excretion, mg/2 h & $0.09 \pm 0.01$ & $0.06 \pm 0.01^{*}$ & $0.04 \pm 0.01^{*}$ & $0.06 \pm 0.01^{*}$ \\
$\mathrm{~K}^{+}$excretion, $\mu \mathrm{mol} / 2 \mathrm{~h}$ & $28.1 \pm 2.3$ & $39.6 \pm 3.8$ & $24.1 \pm 2.5$ & $39.3 \pm 4.5$ \\
$\mathrm{Na}^{+}$excretion, $\mu \mathrm{mol} / 2 \mathrm{~h}$ & $1.72 \pm 0.17$ & $2.14 \pm 0.12^{*}$ & $2.07 \pm 0.18$ & $2.62 \pm 0.24^{*}$ \\
$\mathrm{FENa}^{+}, \%$ & $0.26 \pm 0.03$ & $0.28 \pm 0.02$ & $0.31 \pm 0.04$ & $0.34 \pm 0.05$ \\
$\mathrm{RFNa}^{+}, \mu \mathrm{mol} / \mathrm{min}$ & $60.3 \pm 5.8$ & $57.3 \pm 4.8$ & $54.8 \pm 5.9$ & $52.8 \pm 4.9$ \\
$\mathrm{FFNa}^{+}, \mu \mathrm{mol} / \mathrm{min}$ & $62.4 \pm 5.8$ & $59.5 \pm 3.8$ & $56.8 \pm 6.0$ & $55.4 \pm 4.8$ \\
$\mathrm{RpNa}^{+}, \mathrm{mmol} / 2 \mathrm{~h}$ & $6.82 \pm 0.69$ & $6.07 \pm 0.57$ & $6.27 \pm 0.72$ & $5.81 \pm 0.57$ \\
$\mathrm{RdNa}^{+}, \mathrm{mmol} / 2 \mathrm{~h}$ & $0.65 \pm 0.03$ & $0.61 \pm 0.02$ & $0.55 \pm 0.02$ & $0.52 \pm 0.03$ \\
$\left.\mathrm{GTP}_{\mathrm{m} m o l} / \mathrm{h} \times \mathrm{l}\right)$ & $0.076 \pm 0.011$ & $0.082 \pm 0.01$ & $0.095 \pm 0.009$ & $0.081 \pm 0.012$ \\
\hline
\end{tabular}

Note. $\mathrm{P}_{\mathrm{cr}}-$ blood plasma creatinine content, $\mathrm{FENa}^{+}$- fractional excretion of sodium ions, $\mathrm{RFNa}^{+}-$absolute reabsorption of sodium ions, $\mathrm{FFNa}^{+}$- filtration fraction of sodium ions, $\mathrm{RpNa}^{+}$- proximal reabsorption of sodium ions, $\mathrm{RdNa}^{+}-$distal reabsorption of sodium ions. ${ }^{*} \mathrm{P} \leq 0.05$ as compared to the control group. 
between distal sodium reabsorption and GFR ( $\mathrm{r}$ $=-0.92$ in ATO, $r=-0.59$ in LOV, and $r=-0.84$ in SIM), and between distal sodium reabsorption and sodium filtration fraction $(\mathrm{r}=-0.57$ in $\mathrm{ATO}$, $r=-0.59$ in LOV, and $r=-0.79$ in SIM). On the glomerular-vascular level moderate correlation dependence of plasma creatinine on GFR was established ( $r=0.60$ on an average for all statins).

It may also be argued that the administration mode and selected doses of statins were effective regarding the lipid-lowering action as evidenced by the tendency to reduction of plasma TC in ATO and LOV, and more marked decrease in SIM - by 33\% (Fig. 1). Plasma LDL content declined most distinctly in SIM by $16 \%$, and two other statins only demonstrated a downward trend. A moderate influence on lipid metabolism can be explained by a short-term administration of drugs and the absence of a pathological process that would require correction.

Considering that statins are able to realize their pharmacological potential not only through lipid-lowering actions, but also due to their pleiotropic properties, the influence of drugs on the free radical oxidation as the most universal mechanism of pathological processes was studied [15]. There were no dramatic changes in prooxidant-antioxidant balance in the kidney tissues caused by statins (Table 2). The latter

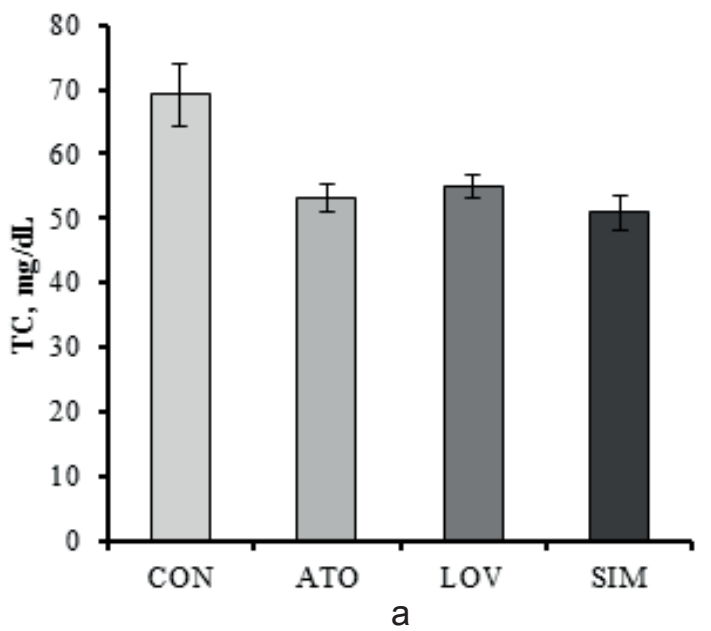

fact can be explained by the lack of alterations of the physiological balance in terms of the experiment, while expression of pleiotropic properties of statins is largely manifested under the conditions of pathology. To illustrate: the most pronounced effect of statins was observed in reduction of the kidney MDA content by $40 \%$ in SIM, and in the kidney CAT activity increased by $17 \%$ and $34 \%$ in ATO and SIM, respectively. The remaining studied indicators - GPx and SOD activity - under the influence of statins were statistically non-significant but showing only upward trends.

It is known that due to the action of reactive oxygen species on the LDL, the latter are modified and in the form of oxidized-LDL reduce activity of produced by endothelium vasodilators and growth inhibitors (prostacyclin, nitric oxide) and also stimulate the formation of vasoconstrictors and growth factors, such as angiotensin II, endotelin-1, plasminogen-1 activator inhibitor [16, 17]. Sure enough, as it has been found in our experiment, changes of kidney function were associated with lipidlowering effect and antioxidant properties of all statins, as evidenced by the correlation between urine protein content and LDL $(r=0.72$ on an average for all statins), between urine protein content and kidney MDA content $(r=0.70$ on an average for all statins).

Fig 1. TC (a) and LDL (b) content in the blood plasma of apparently healthy rats under the conditions of 7-day administration of statins $(\mathrm{M} \pm \mathrm{m}, \mathrm{n}=7){ }^{*} \mathrm{P} \leq 0.05$ as compared to the control group

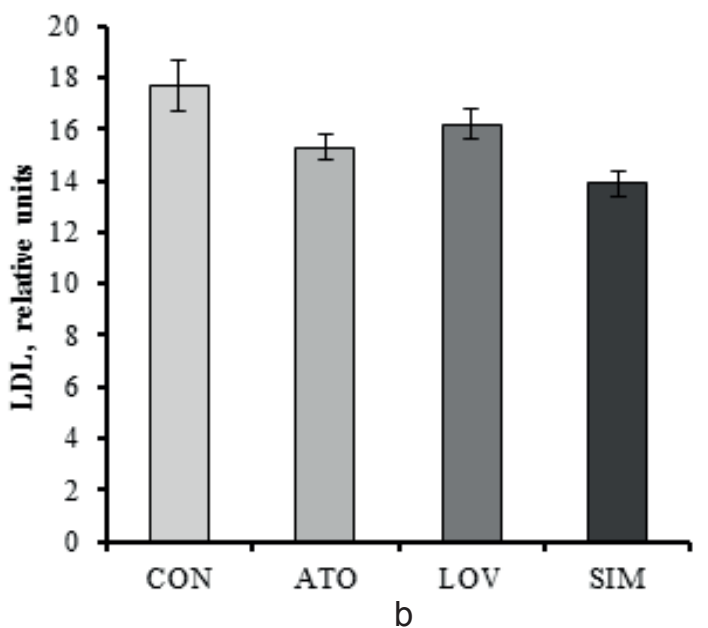


Table 2. Effect of statins on pro- and antioxidant balance in apparently healthy rats on day 7 of the experiment $(\mathrm{M} \pm \mathrm{m}, \mathrm{n}=7)$

\begin{tabular}{l|c|c|c|c|}
\hline \multicolumn{1}{c|}{ Parameter (units) } & CON & ATO & LOV & SIM \\
\hline MDA, $\mu \mathrm{mol} / \mathrm{g}$ protein & $63.8 \pm 4.4$ & $49.0 \pm 3.6$ & $54.6 \pm 3.9$ & $45.6 \pm 1.7^{*}$ \\
CAT, $\mu \mathrm{mol} \mathrm{H}_{2} \mathrm{O}_{2} /$ g protein per min & $10.1 \pm 1.7$ & $11.8 \pm 0.3$ & $10.3 \pm 0.61$ & $13.5 \pm 0.9^{*}$ \\
GSH-Px, nmol/mg protein per min & $226.5 \pm 14.4$ & $238.1 \pm 6.9$ & $233.2 \pm 14.0$ & $240.8 \pm 10.6$ \\
SOD, U/mg protein & $2.51 \pm 0.09$ & $2.64 \pm 0.14$ & $25.7 \pm .0 .10$ & $2.77 \pm 0.11$ \\
\hline
\end{tabular}

${ }^{*} \mathrm{P} \leq 0.05$ as compared to the control group.

Oxidized-LDL can stimulate the secretion of increased amounts of proinflammatory cytokines (IL-1 $\beta$, IL-6, TNF- $\alpha$ ) by monocytes/macrophages in blood, which are an important link in many pathological processes and are able to engage each other in a series of cascading events resulting in a synergistic potentiation with pathobiological effects [18], as well as affect renal potassium channels and therefore cause renal dysfunction [19]. Statins possess the ability to prevent that pathological cascade by decreasing production of LDL.

As it has been found in our experiments, at the $7^{\text {th }}$ day of the experiment use of statins resulted in a slight decrease in the blood plasma cytokines concentration with some distinctions between different groups of drugs. The fullest possible extent of plasma IL- $1 \beta$ reduction by $25 \%$ was established in SIM, alternatively, ATO and LOV administration led to less prominent decrease of IL- $1 \beta$ - by $19 \%$ and by $11 \%$, respectively. Likewise the IL-6 plasma concentration reduced in ATO by $27 \%$, LOV - by $13 \%$, and SIM - by $19 \%$. The most pronounced reduction of TNF- $\alpha$ content by $33 \%$ was observed in SIM, and the least, by $21 \%$, - in LOV. By comparing the effect of studied drugs on the level of proinflammatory cytokines one can conclude that SIM most significantly decreased IL- $1 \beta$ and
TNF- $\alpha$ content, ATO - IL- 6 content, and LOV less actively affected the cytokine profile.

Considering the obtained results, renal effects of statins can be explained by the pronouncement of their pleiotropic effects and interconnections between the parameters of renal function, LDL content and markers of inflammation on an average for all statins: IL- $1 \beta$ and LDL $(r=0.50)$, IL-1 $\beta$ and urine protein content $(\mathrm{r}=0.61)$, IL-1 $\beta$ and potassium excretion $(\mathrm{r}=$ $0.42)$. Such dependency was recorded for IL-6 $(\mathrm{r}=0.86 ; \mathrm{r}=0.54 ; \mathrm{r}=0.34$, respectively) and TNF- $\alpha(r=0.82 ; r=0.80 ; r=0.40$, respectively). Considering a drug with the highest in the context of our experiment antiatherogenic activity - SIM - there was established a strong correlation between IL- $1 \beta$ and LDL $(r=0.84)$, IL- $1 \beta$ and urine protein content $(r=0.71)$, IL-1 $\beta$ and potassium excretion $(\mathrm{r}=0.42)$.

Studying the myotropic effect of statins, we observed no considerable increase in CPK activity as compared to $\mathrm{CON}$, though the upward trend of this indicator in LOV was noted (Fig. 2,a), which, however, was not statistically significant. There were no signs of myopathy (ragged red fibers and myocyte necrosis) in the thigh skeletal muscles of LOV rat (Fig. 2,b).

Table 3. Effect of statins $(20 \mathrm{mg} / \mathrm{kg})$ on the plasma content of cytokines in apparently healthy rats $(\mathrm{M} \pm \mathrm{m}, \mathrm{n}=7)$

\begin{tabular}{|l|c|c|c|c|}
\hline \multicolumn{1}{|c|}{ Parameter (units) } & CON & ATO & LOV & SIM \\
\hline IL-1 $\beta, \mathrm{pg} / \mathrm{ml}$ & $9.31 \pm 0.64$ & $7.82 \pm 0.38$ & $8.39 \pm 0.43$ & $7.45 \pm 0.29^{*}$ \\
IL-6, pg/ml & $14.18 \pm 0.85$ & $11.17 \pm 0.54^{*}$ & $12.55 \pm 0.62$ & $11.62 \pm 0.73$ \\
TNF- $\alpha, \mathrm{pg} / \mathrm{ml}$ & $5.45 \pm 0.65$ & $4.26 \pm 0.28$ & $4.58 \pm 0.27$ & $4.17 \pm 0.19$
\end{tabular}

${ }^{*} \mathrm{P} \leq 0.05$ as compared to the control group. 


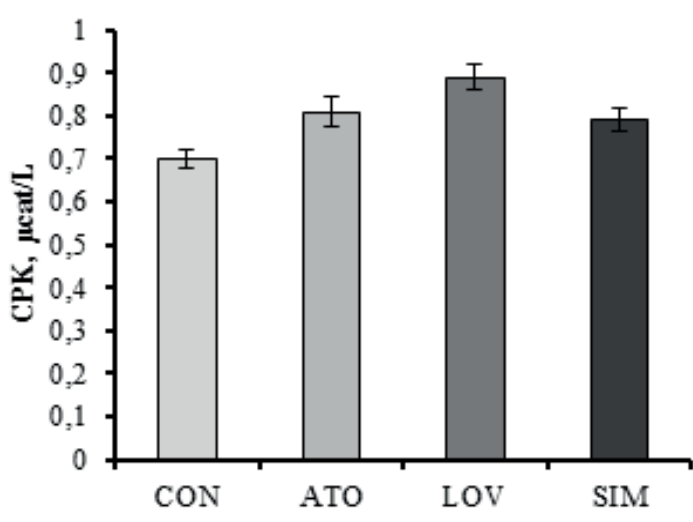

a

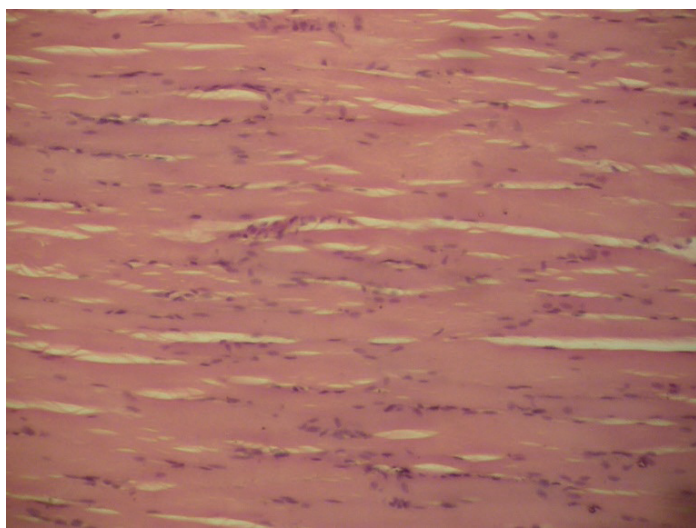

b

Fig 2. Myotropic effect of statins, represented as CPK activity in the blood plasma of apparently healthy rats (a) and as thigh skeletal muscles of LOV rat without evidences of myopathy (b). Stained with hematoxylin and eosin, $\times 100$

Considering the potential hepatotoxicity of statins, the levels of plasma ALT and AST were assessed. It was established that statins caused only a tendency to increase in liver transaminases in the blood plasma, which had no statistical verification: ALT by $7 \%$ and AST by $4 \%$ on an average for all statins (Fig. 3). We can assume that a slight increase in enzyme activity might be caused by metabolism of statins in the liver.

\section{DISCUSSION}

Obtained as a result of research, a weak increase in diuresis may be explained by pleiotropic effects of statins, however literature data on this

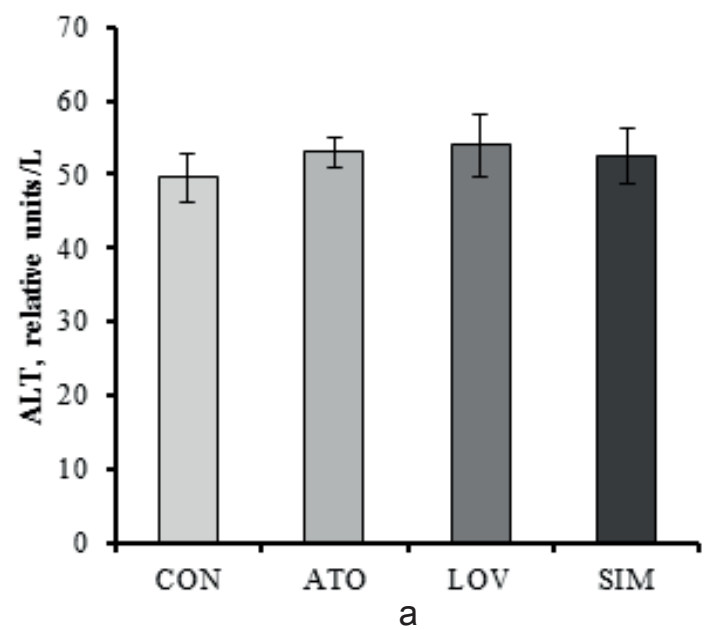

issue are controversial. Accordingly, represented data regarding the possible influence of statins on RAAS by suppression of aldosterone and angiotensin II synthesis as well as a decrease in expression of receptors for angiotensin II suggests an increase in urinary output [9]; on the contrary, an increased expression of aquaporines 2 might cause the opposite effect [8]. Thus, further in-depth research is needed to assess the above mentioned mechanisms and their therapeutic significance. Besides that, it can be assumed that the profile of statins pleiotropic effects in rats might be different from hominal: it should be noted the impossibility of complete extrapolation of the experimental data on the respective statins

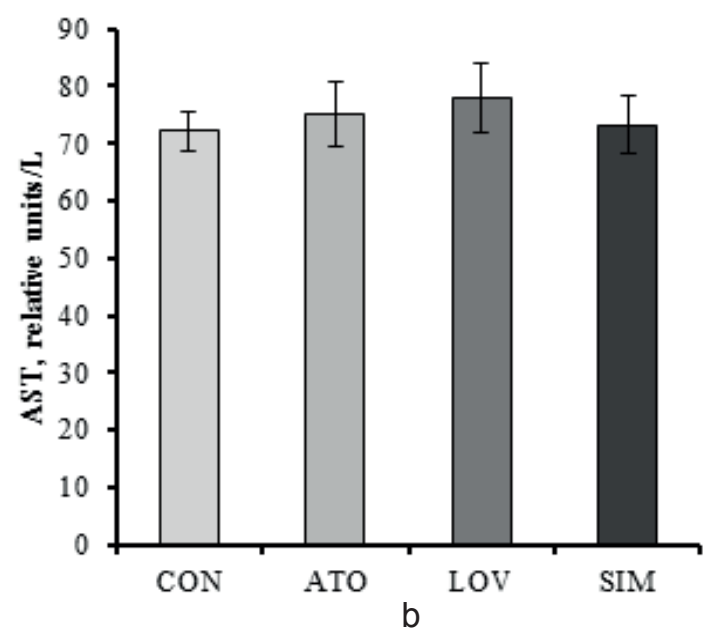

Fig 3. ALT (a) and AST (b) content in the blood plasma of apparently healthy rats under the conditions of 7-day administration of statins $(\mathrm{M} \pm \mathrm{m}, \mathrm{n}=7)$ 
mechanisms and effects in humans.

Regarding the prospects for the use of demonstrated statin effects in a clinic, the target group is patients with hyperlipidemia and concomitant severe diseases and agerelated changes. However, besides this, the possibility of practical application of the statins pleiotropic effects in pathogenetic therapy of acute kidney injury as well as for a prevention of this syndrome development is currently being studied (for example, before angiography [20] and in cardiac surgery [21]). In addition, statins are considered by Yang Y. et al. as one of the approaches and strategies of renoprotection in acute kidney injury [22]. Therefore, the results of our research work on the influence of statins on kidneys of apparently healthy rats will allow one to outline the direction of more in-depth study of renotropic effects of statins in animals with experimental pathology.

\section{CONCLUSIONS}

Relying on our data, we may conclude that ATO, LOV and SIM after the 7-day administration to apparently healthy rats at a conventionally effective dose of $20 \mathrm{mg} / \mathrm{kg}$ caused a moderate reduction of TC and LDL, contributed to a slight increase in urination and urine protein reduction with nonsignificant changes in the sodium and potassium balance whilst maintaining basic intrarenal regulatory mechanisms of kidneys functional state.

The above changes may be associated with antioxidant and anti-inflammatory effects of statins. Characteristically, the best results were found with SIM. Selected statin dose and mode of administration did not caused myolysis development and increased activity of transaminases within a week of application.

\section{В.Г. Зеленюк, I.I. Заморський, О.В. Геруш, Т.С. Щудрова, О.М. Горошко, А.Р. Зеленюк ПОРІВНЯЛЬНА ОЦІНКА РЕНАЛЬНИХ, ПЛЕЙО- ТА МІОТРОПНИХ ЕФЕКТІВ СТАТИНІВ У ЩУРІВ}

Досліджено вплив деяких статинів із різною ліпофільністю (аторва-, лова-, симвастатин) на функціональ- ний стан нирок здорових щурів при застосуванні в раніше встановлених умовноефективній дозі 20 мг/кг. Доведено, що на 7-й день уведення статинів у щурів виявляли лише помірне підвищення діурезу з незначним зростанням швидкості клубочкової фільтрації та екскреції іонів натрію, а також зменшенням екскреції білка із сечею при збереженні механізмів внутрішньониркової авторегуляції. Нефротропна дія статинів, серед інших механізмів, була викликана їх плейотропними ефектами, що підтверджувалось наявністю відповідних кореляцій. Антиоксидантна дія препаратів виявлялась у зменшенні в нирках вмісту малонового діальдегіду та підвищенням активності каталази. Протизапальна дія відображалась у наявності тенденції до зниження вмісту у плазмі крові прозапальних цитокінів (інтерлейкіну-1 $\beta$, інтерлейкіну-6, фактора некрозу пухлин $\alpha$ ). Продемонстровано відсутність впливу статинів на вміст печінкових трансаміназ, концентрацію креатинфосфокінази в плазмі крові та гістоструктуру скелетних м>язів. Найбільш виражений ренальний ефект серед трьох препаратів виявлено у симвастатину - за зменшенням протеїнурії у 2 рази, збільшенням діурезу та екскреції іонів натрію у 1,2 та 1,52 раза відповідно.

Ключові слова: статини; функція нирок; здорові щури; про- та антиоксидантний баланс; інтерлейкіни

Вищий державний навчальний заклад України «Буковинський державний медичний університет», Чернівиі; e-mail:vzeleniuk@gmail.com

\section{В.Г. Зеленюк, И.И. Заморский, О.В. Геруш, Т.С. Щудрова, А.М. Горошко, А.Р. Зеленюк \\ СРАВНИТЕЛЬНАЯ ОЦЕНКА ПОЧЕЧНЫХ, ПЛЕЙО- И МИОТРОПНЫХ ЭФФЕКТОВ СТАТИНОВ У КРЫС}

Исследовано влияние некоторых статинов с разной липофильностью (аторва-, лова-, симвастатин) на функциональное состояние почек здоровых крыс при применении в ранее установленных условноэффективной дозе 20 мг/кг. Доказано, что на 7-й день введения статинов у крыс определяли лишь умеренное повышение диуреза с незначительным ростом скорости клубочковой фильтрации и экскреции ионов натрия, а также уменьшением экскреции белка с мочой при сохранении механизмов внутрипочечной авторегуляции. Нефротропное действие статинов, среди других механизмов, было вызвано их плейотропными эффектами, что подтверждалось наличием соответствующих корреляций. Антиоксидантное действие препаратов проявлялась в уменьшении в почках содержания малонового диальдегида и повышением активности каталазы. Противовоспалительное действие отражалась в наличии тенденции к снижению содержания в плазме крови провоспалительных цитокинов (интерлейкина$1 \beta$, интерлейкина- 6 , фактора некроза опухолей $\alpha$ ). Продемонстрировано отсутствие влияния статинов на 
содержание печеночных трансаминаз, концентрацию креатинфосфокиназы в плазме крови и гистоструктуры скелетных мышц. Наиболее выраженный ренальный эффект среди испытуемых препаратов обнаружено у симвастатина - по уменьшению протеинурии в 2 раза, увеличению диуреза и экскреции ионов натрия в 1,2 и 1,52 раза соответсвенно.

Ключевые слова: статины; функция почек; здоровые крысы; про- и антиоксидантный баланс; интерлейкины.

\section{REFERENCES}

1. Davies JT, Delfino SF, Feinberg CE, Johnson MF, Nappi VL, Olinger JT, et al. Current and emerging uses of statins in clinical therapeutics: a review. Lipid Insights. 2016;9:13-29.

2. Kavalipati N, Shah N, Ramakrishan A, Vasnawala H. Pleiotropic effects of statins. Indian J Endocrinol Metab. 2015;19(5):554-62.

3. Amann K, Benz K. Statins - beyond lipids in CKD. Nephrol Dial Transplant. 2011;26:407-10.

4. Wu K, Lei W, Tian J, Li H. Atorvastatin treatment attenuates renal injury in an experimental model of ischemiareperfusion in rats. BMC Nephrology [Internet]. 2014 [cited Jun 29];15:14. Available from: http://www.biomedcentral. com/1471-2369/15/14 doi: 10.1186/1471-2369-15-14

5. Burgazli KM, Bui KL, Mericliler M, Albayrak AT, Parahuleva M, Erdogan A. The effects of different types of statins on proliferation and migration of HGF-induced Human Umbilical Vein Endothelial Cells (HUVECs). Eur Rev Med Pharmacol Sci. 2013;17(21):2874-83.

6. Antonopoulos AS, Margaritis M, Lee R, Channon K, Antoniades C. Statins as anti-inflammatory agents in atherogenesis: molecular mechanisms and lessons from the recent clinical trials. Curr Pharm Des. 2012;18(11):1519-30.

7. Violi F, Calvieri C, Ferro D, Pignatelli P. Statins as antithrombotic drugs. Circulation. 2013;127:251-57.

8. Bonfrate L, Procino G, Wang DQH, Svelto M, Portincasa P. A novel therapeutic effect of statins on nephrogenic diabetes insipidus. J. Cell. Mol. Med. 2015;19(2):265-82.

9. Drapala A, Sikora M, Ufnal M. Statins, the reninangiotensin-aldosterone system and hypertension - a tale of another beneficial effect of statins. J Renin-AngiotensinAldosterone Syst. 2014;15(3):250-58.
10. Paulsen L, Holm C, Bech JN, Starklint J, Pedersen EB. Effects of statins on renal sodium and water handling. Nephrol Dial Transplant. 2008;23:1556-61.

11. Maji D, Shaikh S, Solanki D, Gaurav K. Safety of statins. Indian J Endocrinol Metab. 2013;17(4):636-46.

12. Zeleniuk VG, Zamorskii II, Goroshko OM. Renoprotective efficacy of different doses of statins in experimental acute renal failure. Fiziol Zh. 2014;60(2): 75-81.

13. Clinical Methods: The History, Physical, and Laboratory Examinations. Editors: Walker H.K., Hall W.D., Hurst J.W. 3rd edition [Internet]. Boston: Butterworths; 1990 [cited 2017 Jun 29]. Available from: https://www.ncbi.nlm.nih. gov/books/NBK201/

14. Szasz G. A kinetic photometric method for serum gammaglutamyl transpeptidase. Clin Chem. 1969;15(2):124-36.

15. Lechleitner M. Non lipid related effects of statins. J Clin Basic Cardiol. 2002 5(3):205-8.

16. Moon GJ, Kim SJ, Cho YH, Ryoo S, Bang OY. Antioxidant Effects of Statins in Patients with Atherosclerotic Cerebrovascular Disease. J Clin Neurol. 2014;10(2):140-7.

17. Trevisan R, Dodesini AR, Lepore G. Lipids and Renal Disease. JASN. 2006;17(4,2):S145-7.

18. Ortega ML, Fornoni A. Role of cytokines in the pathogenesis of acute and chronic kidney disease, glomerulonephritis, and end-stage kidney disease. Int J Interferon, Cytokine and Mediat Res. 2010;2:49-62.

19. Nakamura K, Hayashi H, Kubokawa M. Proinflammatory cytokines and potassium channels in the kidney. Mediators Inflamm [Internet]. 2015 [cited 2017 Jun 29]. Available from: https://www.hindawi.com/journals/mi/2015/362768/ DOI: $10.1155 / 2015 / 362768$.

20. Xiao-lei W, Tuo Z, Liu-hua $\mathrm{H}$ et al. Comparison of effects of different statins on contrast-induced acute kidney injury in rats: histopathological and biochemical findings. Oxid Med Cell Longev. 2017 2017:a6282486. doi: 10.1155/2017/6282486.

21. Xiong B, Nie D, Cao Y, Zou Y, Yao Y, Qian J, et al. Preoperative statin treatment for the prevention of acute kidney injury in patients undergoing cardiac surgery: a meta-analysis of randomised controlled trials. Heart Lung Circ. 2017;26(11):1200-1207. doi: 10.1016/j. hlc.2016.11.024.

22. Yang Y, Song M, Liu Y, Liu H, Sun L, Peng Y et al. Renoprotective approaches and strategies in acute kidney injury. Pharmacol Ther. 2016;163:58-73. 